\title{
Water Extractable Phytochemicals from Peppers (Capsicum spp.) Inhibit Acetylcholinesterase and Butyrylcholinesterase Activities and Prooxidants Induced Lipid Peroxidation in Rat Brain In Vitro
}

\author{
Omodesola O. Ogunruku, ${ }^{1,2}$ Ganiyu Oboh, ${ }^{2}$ and Ayokunle O. Ademosun ${ }^{2}$ \\ ${ }^{1}$ Department of Biochemistry, Obafemi Awolowo University, Ile Ife 220282, Nigeria \\ ${ }^{2}$ Functional Foods and Nutraceuticals Unit, Department of Biochemistry, Federal University of Technology, \\ PMB 704, Akure, Ondo State 340001, Nigeria \\ Correspondence should be addressed to Ganiyu Oboh; goboh2001@yahoo.com
}

Received 17 June 2014; Revised 10 November 2014; Accepted 13 November 2014; Published 4 December 2014

Academic Editor: Rong Di

Copyright (C) 2014 Omodesola O. Ogunruku et al. This is an open access article distributed under the Creative Commons Attribution License, which permits unrestricted use, distribution, and reproduction in any medium, provided the original work is properly cited.

\begin{abstract}
Background. This study sought to investigate antioxidant capacity of aqueous extracts of two pepper varieties (Capsicum annuum var. accuminatum (SM) and Capsicum chinense (RO)) and their inhibitory effect on acetylcholinesterase and butyrylcholinesterase activities. Methods. The antioxidant capacity of the peppers was evaluated by the 2,2' -azino-bis(3-ethylbenzthiazoline-6-sulphonic acid) (ABTS) radical scavenging ability and ferric reducing antioxidant property. The inhibition of prooxidant induced lipid peroxidation and cholinesterase activities in rat brain homogenates was also evaluated. Results. There was no significant difference $(P>0.05)$ in the total phenol contents of the unripe and ripe Capsicum spp. extracts. Ripe and unripe SM samples had significantly

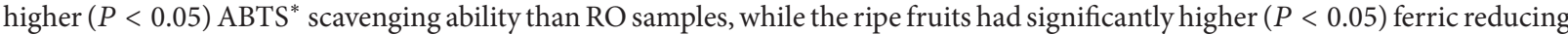
properties in the varieties. Furthermore, the extracts inhibited $\mathrm{Fe}^{2+}$ and quinolinic acid induced lipid peroxidation in rats brain homogenates in a dose-dependent manner. Ripe and unripe samples from SM had significantly higher AChE inhibitory abilities than RO samples, while there was no significant difference in the BuChE inhibitory abilities of the pepper samples. Conclusion. The antioxidant and anticholinesterase properties of Capsicum spp. may be a possible dietary means by which oxidative stress and symptomatic cognitive decline associated with neurodegenerative conditions could be alleviated.
\end{abstract}

\section{Introduction}

Alzheimer's disease (AD) is characterized by progressive cognitive, functional, and behavioral impairment, which evolves into a dramatic loss of most cortical and subcortical functions and, ultimately, death [1]. Demographic changes and the rise in life expectancy have resulted in the growth recorded in the number of individuals affected by AD. It is forecast that the worldwide number of elderly people suffering from dementia will rise to 63 million in 2030 and to 114 million in 2050 [2]. The socioeconomic impact associated with the global $\mathrm{AD}$ burden that cannot be estimated raises the need to find preventive and palliative means of treatment for sufferers.
Deficiency of the neurotransmitter acetylcholine at the synaptic cleft coupled with cholinergic decline in the hippocampal and cortical regions of the brain is associated with cognitive decline observed in $\mathrm{AD} \mathrm{[3],} \mathrm{a} \mathrm{situation} \mathrm{which} \mathrm{is} \mathrm{fur-}$ ther aggravated by deposition of amyloid proteins observed in senile plaques in the extracellular matrix of the brain [4]. There is evidence that cholinesterase inhibitors (ChEIs) may slow disease progression and hippocampal atrophy and may have disease-modifying effects [5]. Furthermore, treatments with ChEIs have been found to have a positive correlation with improved cognitive abilities with modest and significant therapeutic effects [6]. Thus, restoring the level of acetylcholine through inhibition of both major 
forms of cholinesterases, acetylcholinesterase (AChE), and butyrylcholinesterase $(\mathrm{BuChE})$ is considered to be a useful therapeutic approach $[7,8]$. While all approved ChEIs (donepezil, rivastigmine, and galantamine) inhibit both forms of cholinesterases, however, continued search among natural products has intensified due to adverse side effects associated with these drugs.

Furthermore, the mammalian brain is particularly sensitive towards oxidative damage, a result of the high oxygen demand and the high content of unsaturated lipids in the central nervous system [9] coupled with the reduced access to the antioxidant defense system and the high amount of redox-active transition metal ions [10, 11]. Oxidative stress in the central nervous system is an underlying cause of neurodegeneration and neural dysfunction [12]. This has resulted in considerable research efforts being put towards reducing the risks and event of oxidative stress with the use of antioxidants.

Peppers (Capsicum spp.), a genus of related plants, belong to the family Solanaceae and have a worldwide distribution. They are important as vegetable foods and spice and are considered an important source of nutrients in the human diet which are grown in tropical, subtropical, and temperate regions [13-15]. Various species and varieties occurring within the Capsicum genus depending on their shape, size, flavor, and hotness include Capsicum annum, Capsicum frutescence, and Capsicum chinense. Previous studies $[16,17]$ have highlighted some of the health benefits associated with the consumption of Capsicum spp. Therefore, this study sought to assess the ability of pepper fruits to interact with some enzymes (acetylcholinesterase and butyrylcholinesterase) which are implicated in AD pathology $v i s-\grave{a}$-vis the antioxidant capacity of the pepper fruits.

\section{Materials and Methods}

\subsection{Materials}

2.1.1. Sample Collection. Fresh samples of two samples of peppers both ripe and unripe "sombo" (Capsicum annuum var. accuminatum) and "ata rodo" (Capsicum chinense) were collected from farm settlements around Akure Metropolis, Nigeria. Authentication of the samples was carried out at the Department of Biology, Federal University of Technology, Akure, Nigeria.

2.1.2. Sample Preparation. The samples were washed and homogenized in distilled water $(1: 20 \mathrm{w} / \mathrm{v})$. These were later centrifuged at $4000 \mathrm{rpm}$ for five minutes, and the supernatant was collected which was stored at $4^{\circ} \mathrm{C}$ until further analysis.

2.1.3. Chemicals and Reagents. Chemicals and reagents used such as thiobarbituric acid (TBA), 1,10-phenanthroline, deoxyribose, gallic acid, and Folin-Ciocalteau's reagent were procured from Sigma-Aldrich, Inc. (St Louis, MO), trichloroacetic acid (TCA) was sourced from Sigma-Aldrich, Chemie GmbH (Steinheim, Germany), dinitrophenylhydrazine (DNPH) was sourced from ACROS Organics
(New Jersey, USA), and hydrogen peroxide, methanol, acetic acid, thiourea, $\mathrm{CuSO}_{4} \cdot 5 \mathrm{H}_{2} \mathrm{O}, \mathrm{H}_{2} \mathrm{SO}_{4}, \mathrm{HCl}$, sodium carbonate, $\mathrm{AlCl}_{3}$, potassium acetate, Tris- $\mathrm{HCl}$ buffer, sodium dodecyl sulphate, $\mathrm{FeSO}_{4}$, potassium ferricyanide, and ferric chloride were sourced from BDH Chemicals Ltd. (Poole, England), while the water was glass distilled.

2.1.4. Experimental Animals. Approval was obtained from the relevant departmental ethics committee responsible for the use of laboratory animals. The handling and the use of the animals were in accordance with NIH Guide for the care and use of laboratory animals. Adult male Wistar strain albino rats were purchased from the Department of Biochemistry, University of Ilorin. All animals were given ad libitum access to commercial diet and maintained on a $12 \mathrm{~h}$ light/dark cycle. All ethical standards regarding the use of animals in experimental procedures were strictly adhered to.

\subsection{Methods}

2.2.1. Determination of Total Phenol Content. The total phenol content was determined according to the method of Singleton et al. [18]. Briefly, appropriate dilutions of the aqueous extracts were oxidized with $2.5 \mathrm{~mL} 10 \%$ FolinCiocalteau's reagent (v/v) and neutralized by $2.0 \mathrm{~mL}$ of $7.5 \%$ sodium carbonate. The reaction mixture was incubated for $40 \mathrm{~min}$ at $45^{\circ} \mathrm{C}$ and the absorbance was measured at $765 \mathrm{~nm}$ in the JENWAY UV-visible spectrophotometer. The total phenol content was subsequently calculated as gallic acid equivalent.

\subsubsection{In Vitro Antioxidant Studies}

2,2'-Azino-bis(3-ethylbenzthiazoline-6-sulphonic acid) (ABTS) Radical Scavenging Ability. The ABTS* scavenging ability of the extracts was determined according to the method described by Re et al. [19]. The ABTS* was generated by reacting an $(7 \mathrm{mmol} / \mathrm{L})$ ABTS aqueous solution with $\mathrm{K}_{2} \mathrm{~S}_{2} \mathrm{O}_{8}$ $(2.45 \mathrm{mmol} / \mathrm{L}$, final concentration) in the dark for $16 \mathrm{~h}$ and adjusting the absorbance at $734 \mathrm{~nm}$ to 0.700 with ethanol. $0.2 \mathrm{~mL}$ of appropriate dilution of the extract was added to $2.0 \mathrm{~mL} \mathrm{ABTS}^{*}$ solution and the absorbance was measured at $734 \mathrm{~nm}$ after $15 \mathrm{~min}$ in the JENWAY UV-visible spectrophotometer. The Trolox equivalent antioxidant capacity (TEAC) was subsequently calculated.

2.2.3. Determination of Reducing Property. The reducing property of the extracts was determined by assessing the ability of the extract to reduce $\mathrm{FeCl}_{3}$ solution as described by Oyaizu [20]. $2.5 \mathrm{~mL}$ aliquot was mixed with $2.5 \mathrm{~mL} 200 \mathrm{mM}$ sodium phosphate buffer ( $\mathrm{pH} 6.6$ ) and $2.5 \mathrm{~mL} 1 \%$ potassium ferricyanide. The mixture was incubated at $50^{\circ} \mathrm{C}$ for $20 \mathrm{~min}$, and then $2.5 \mathrm{~mL} 10 \%$ trichloroacetic acid was added. This mixture was centrifuged at $650 \mathrm{rpm}$ for $10 \mathrm{~min}$. $5 \mathrm{~mL}$ of the supernatant was mixed with an equal volume of water and $1 \mathrm{~mL} 0.1 \%$ ferric chloride. The absorbance was measured at $700 \mathrm{~nm}$ in the JENWAY UV-visible spectrophotometer. The ferric reducing antioxidant property was subsequently calculated as ascorbic acid equivalent. 


\subsubsection{Lipid Peroxidation Assay}

Preparation of Tissue Homogenates. The rats were decapitated under mild diethyl ether anaesthetic conditions and the whole brain tissue was quickly isolated and placed on ice and weighed. The tissue was subsequently homogenized in cold saline $(1 / 10 \mathrm{w} / \mathrm{v})$ with about $10 \mathrm{up}$-and-down strokes at approximately $1200 \mathrm{rev} / \mathrm{min}$ in a Teflon glass homogenizer. The homogenates were centrifuged for $10 \mathrm{~min}$ at $3000 \mathrm{rpm}$ to yield pellets that were discarded, and a low-speed supernatant (S1) fraction was kept for lipid peroxidation assay [21].

\subsubsection{Lipid Peroxidation and Thiobarbituric Acid Reactions.}

The lipid peroxidation assay was carried out using the modified method of Ohkawa et al. [22]. Briefly $100 \mu \mathrm{L} \mathrm{S1}$ fraction was mixed with a reaction mixture containing $30 \mu \mathrm{L}$ of $0.1 \mathrm{M} \mathrm{pH} 7.4$ Tris- $\mathrm{HCl}$ buffer extract $(0-100 \mu \mathrm{L})$ and $30 \mu \mathrm{L}$ of $250 \mu \mathrm{M}$ freshly prepared $\mathrm{FeSO}_{4}$ (the procedure was also carried out using $5 \mathrm{mM}$ sodium nitroprusside and $15 \mathrm{mM}$ quinolinic acid). The volume was made up to $300 \mu \mathrm{L}$ by water before incubation at $37^{\circ} \mathrm{C}$ for $1 \mathrm{~h}$. The colour reaction was developed by adding $300 \mu \mathrm{L} 8.1 \%$ sodium dodecyl sulphate (SDS) to the reaction mixture containing S1, and this was subsequently followed by the addition of $500 \mu \mathrm{L}$ of acetic acid/HCl (pH 3.4) mixture and $500 \mu \mathrm{L} 0.8 \%$ thiobarbituric acid (TBA). This mixture was incubated at $100^{\circ} \mathrm{C}$ for $1 \mathrm{~h}$. Thiobarbituric acid reactive species (TBARS) produced were measured at $532 \mathrm{~nm}$ in the JENWAY UVvisible spectrophotometer and the absorbance was compared with that of standard curve using malondialdehyde (MDA).

\subsubsection{Acetylcholinesterase (AChE) and Butyrylcholinesterase} (BuChE) Inhibition Assay. The AChE inhibitory activity was determined according to the method of Ellman et al. [23] in a reaction mixture containing $200 \mu \mathrm{L}$ of $\mathrm{AChE}$ solution in $0.1 \mathrm{M}$ phosphate buffer, $\mathrm{pH} 8.0,100 \mu \mathrm{L}$ of a solution of 5,5-dithiobis-(2-nitrobenzoic) acid (3.3 mM DTNB in $0.1 \mathrm{M}$ phosphate buffered solution, $\mathrm{pH} 7.0$, containing $6 \mathrm{mM}$ $\left.\mathrm{NaHCO}_{3}\right), 100 \mu \mathrm{L}$ of a solution of the inhibitor, and $500 \mu \mathrm{L}$ of phosphate buffer, $\mathrm{pH}$ 8.0. After incubation for $20 \mathrm{~min}$ at $25^{\circ} \mathrm{C}$, $0.05 \mathrm{mM}$ of acetylthiocholine iodide $(100 \mu \mathrm{L})$ was added as the substrate, and AChE activity was determined by UVvisible spectrophotometer from the absorbance changes at $412 \mathrm{~nm}$ for $3 \mathrm{~min}$ at $25^{\circ} \mathrm{C}$.

$100 \mu \mathrm{L}$ of $0.05 \mathrm{mM}$ butyrylthiocholine iodide was used as a substrate to assay BuChE enzyme activity while all the other reagents and conditions were the same. The AChE and BuChE inhibitory activities were expressed as percentage inhibition.

2.2.7. Data Analysis. The results of the three replicates were pooled and expressed as mean \pm standard deviation (STD). A two-way analysis of variance (ANOVA) and the least significant difference (LSD) were also determined. Significance was accepted at $P<0.05$.
TABLE 1: Total phenolic content of the aqueous extract of Capsicum spp. (mg/g sample).

\begin{tabular}{lcc}
\hline & Unripe & Ripe \\
\hline SM & $14.09 \pm 1.09^{\mathrm{a}}$ & $13.28 \pm 0.93^{\mathrm{a}}$ \\
RO & $14.17 \pm 1.27^{\mathrm{a}}$ & $13.66 \pm 1.09^{\mathrm{a}}$ \\
\hline
\end{tabular}

Values represent means of triplicate. Values with the same letter along the same column are not significantly different $(P>0.05)$. SM: Capsicum annuum var. accuminatum; RO: Capsicum chinense.

\section{Results}

The results for the total phenol content of the aqueous extract of ripe and unripe fruits of Capsicum annuum var. accuminatum (SM) and Capsicum chinense (RO) are presented in Table 1. There was no significant difference $(P>0.05)$ in the total phenol contents of the unripe (SM (14.09 mg/g); RO (14.17 mg/g)) and ripe (SM (13.28 mg/g); RO (13.66 mg/g)) Capsicum spp. extracts. The ABTS* scavenging ability reported as Trolox equivalent antioxidant capacity (TEAC) is presented in Figure 1. Extracts from both Capsicum spp. were able to scavenge ABTS* . There was no significant difference $(P>0.05)$ in the scavenging ability of the ripe and unripe SM samples, while unripe RO extracts showed a significantly higher $(P<0.05)$ scavenging ability than the ripe. The ferric reducing ability of the aqueous extracts reported as ascorbic acid equivalent as presented in Figure 2 revealed that the ripe SM and RO extracts had significantly higher $(P<0.05)$ ferric reducing properties than the unripe extracts of the two varieties.

Incubation of rats' brain homogenate with $25 \mu \mathrm{M} \mathrm{Fe} e^{2+}$ resulted in a significant $(P<0.05)$ increase in brain MDA content $(122.80 \%)$ as presented in Figure 3(a). However, the aqueous extracts of the two Capsicum spp. varieties were able to significantly $(P<0.05)$ lower the brain MDA content in a dose-dependent manner in the concentration range of $0.78 \mathrm{mg} / \mathrm{mL}-3.13 \mathrm{mg} / \mathrm{mL}$. The unripe $\mathrm{SM}$ extracts $(3.43 \mathrm{mg} / \mathrm{mL})$ had higher inhibitory ability than the ripe extracts $(3.63 \mathrm{mg} / \mathrm{mL})$, while the ripe $\mathrm{RO}$ extracts $(3.07 \mathrm{mg} / \mathrm{mL})$ had higher inhibitory effect than the unripe $(3.92 \mathrm{mg} / \mathrm{mL})$ (Table 2). Furthermore, the ability of the aqueous extract from pepper fruits to inhibit quinolinic acid (QA) induced lipid peroxidation was assessed and presented in Figure 3(b). Incubation of rats brain homogenate with QA resulted in a significant $(P<0.05)$ increase in brain MDA content (256.67\%). Aqueous extracts from the Capsicum spp. were also able to significantly $(P<0.05)$ lower the brain MDA content in dose-dependent manner. Table 2 revealed that the ripe samples $(\mathrm{SM}(4.87 \mathrm{mg} / \mathrm{mL})$; RO $(4.70 \mathrm{mg} / \mathrm{mL}))$ had significantly higher inhibitory effect than the unripe samples (SM $(5.70 \mathrm{mg} / \mathrm{mL})$; RO $(7.24 \mathrm{mg} / \mathrm{mL}))$. The cholinesterase inhibitory activities of the pepper samples are presented in Figures 4 and 5 and Table 3. Ripe (3.27 $\mathrm{mg} / \mathrm{mL})$ and unripe $(3.19 \mathrm{mg} / \mathrm{mL})$ samples from SM had significantly higher AChE inhibitory abilities than RO (Ripe $(3.72 \mathrm{mg} / \mathrm{mL})$; unripe $(4.27 \mathrm{mg} / \mathrm{mL}))$ samples, while there was no significant difference in the BuChE inhibitory abilities of the unripe $(\mathrm{SM}(3.01 \mathrm{mg} / \mathrm{mL})$; RO $(3.19 \mathrm{mg} / \mathrm{mL}))$ and ripe (SM $(3.22 \mathrm{mg} / \mathrm{mL}) ; \mathrm{RO}(3.38 \mathrm{mg} / \mathrm{mL}))$. 


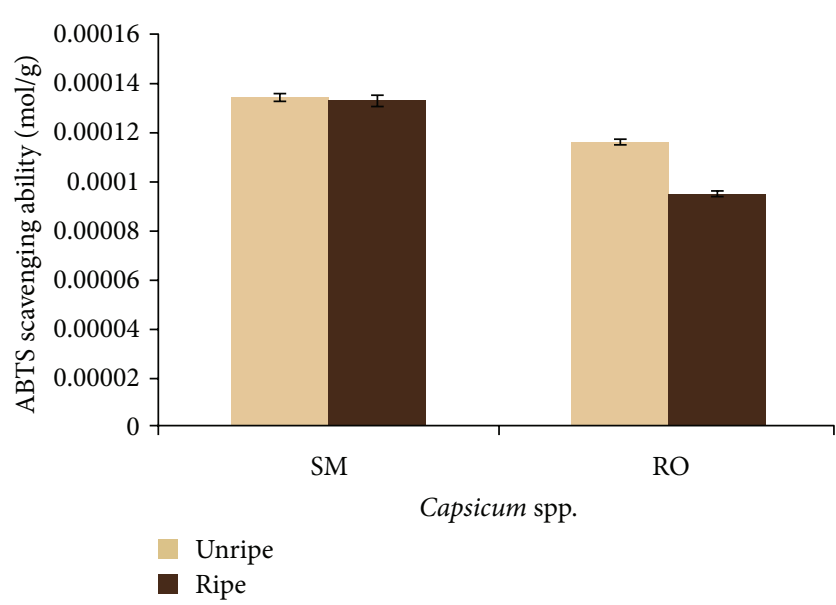

FIgURE 1: ABTS* scavenging ability of Capsicum spp. SM: Capsicum annuum var. accuminatum. RO: Capsicum chinense.

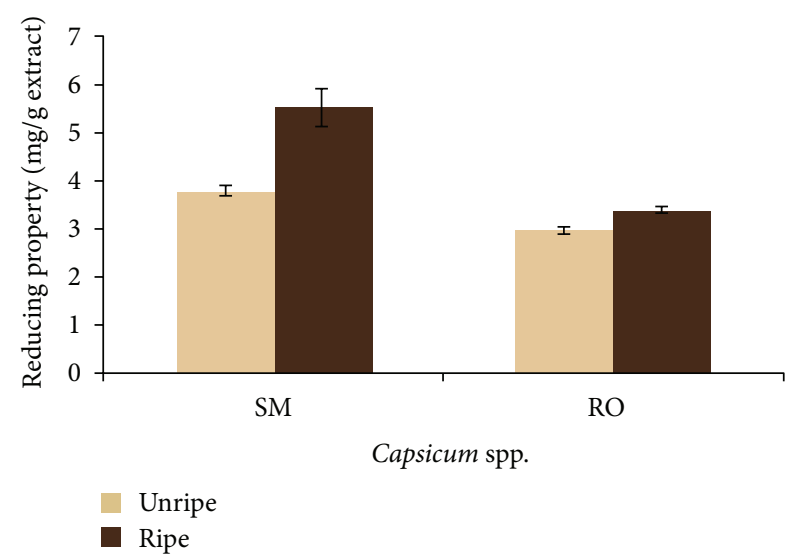

FIGURE 2: Ascorbic acid equivalent Ferric reducing property of aqueous extracts of Capsicum spp. SM: Capsicum annuum var. accuminatum. RO: Capsicum chinense.

\section{Discussion}

Oxidative damage caused by free radicals has been implicated in the development of neurodegenerative conditions [24, 25]. The brain is particularly susceptible to oxidative stress due to its high oxygen content [26]. Therefore, antioxidants could prove effective in the management of neurodegenerative conditions. Antioxidant capacity of the ripe and unripe pepper varieties was studied using a moderately stable nitrogencentered radical species-ABTS radical [19 Re]. The ABTS* scavenging properties of the extracts show their ability to prevent the initiation of oxidation chain reaction that ensues upon free radical generation [27]. Furthermore the extracts were also able to reduce $\mathrm{Fe}^{3+}$ to $\mathrm{Fe}^{2+}$ which is indicative of the reducing power of the extracts. The reversed reaction, which is the oxidation of $\mathrm{Fe}^{2+}$ to $\mathrm{Fe}^{3+}$, is a process by which iron can induce hydroxyl radicals generation in Fenton reaction [28]. The antioxidant properties of the pepper extracts could be linked to their phenolic content as the correlation between phenolic content and antioxidative properties has been
TABLE 2: $\mathrm{EC}_{50}$ values for inhibition of $\mathrm{Fe}^{2+}$ and quinolinic acid induced lipid peroxidation by Capsicum spp. (mg/mL).

\begin{tabular}{lcccc}
\hline \multirow{2}{*}{ Type of pepper } & \multicolumn{2}{c}{$\mathrm{Fe}^{2+}$ induced } & \multicolumn{2}{c}{ QA induced } \\
& Unripe & Ripe & Unripe & Ripe \\
\hline SM & $3.43 \pm 0.09^{\mathrm{a}}$ & $3.63 \pm 0.04^{\mathrm{b}}$ & $5.70 \pm 0.07^{\mathrm{a}}$ & $4.87 \pm 0.06^{\mathrm{a}}$ \\
RO & $3.92 \pm 0.11^{\mathrm{a}}$ & $3.07 \pm 0.09^{\mathrm{a}}$ & $7.24 \pm 0.09^{\mathrm{b}}$ & $4.70 \pm 0.04^{\mathrm{a}}$ \\
\hline
\end{tabular}

Values represent means of triplicates. Values with the same letter along the same column are not significantly different $(P>0.05)$. SM: Capsicum annuum var. accuminatum; RO: Capsicum chinense.

TABLE 3: $\mathrm{EC}_{50}$ values for inhibition of acetylcholinesterase and butyrylcholinesterase in $\mathrm{mg} / \mathrm{mL}$.

\begin{tabular}{lcccc}
\hline \multirow{2}{*}{ Type of pepper } & \multicolumn{2}{c}{ AChE } & \multicolumn{2}{c}{ BuChE } \\
& Unripe & Ripe & Unripe & Ripe \\
\hline SM & $3.19 \pm 0.04^{\mathrm{a}}$ & $3.27 \pm 0.09^{\mathrm{a}}$ & $3.01 \pm 0.03^{\mathrm{a}}$ & $3.22 \pm 0.05^{\mathrm{a}}$ \\
RO & $4.27 \pm 0.03^{\mathrm{b}}$ & $3.72 \pm 0.04^{\mathrm{b}}$ & $3.19 \pm 0.04^{\mathrm{a}}$ & $3.38 \pm 0.02^{\mathrm{a}}$ \\
\hline
\end{tabular}

Values represent means of triplicate. Values along the same column with the same letter are not significantly different. AChE: acetylcholinesterase; BuChE: butyrylcholinesterase; SM: Capsicum annuum var. accuminatum; RO: Capsicum chinense.

established in studies involving a wide range of fruits and vegetables [29-31]. The antioxidant effects of phenolic compounds are attributed to the redox properties of their hydroxy groups achieved through several mechanisms including the scavenging of free radicals, chelation of transition metals serving as prooxidants, activation of antioxidant enzymes, and inhibition of oxidases [32,33]. The higher phenolic content of the unripe Capsicum spp. under study may suggest that there could be a decline in the phenolics synthesis with the event of ripening.

Evidence for the contribution of lipid peroxidation in the brain to the development of neurodegenerative conditions has been found in postmortem brain tissue and patients suffering from Alzheimer's disease [26]. The high amount of polyunsaturated fatty acids and low antioxidant contents of the brain makes it susceptible to lipid peroxidation [34]. Lipid peroxidation is associated with loss of membrane fluidity and increase in permeability ultimately resulting in loss of membrane structure and function [35]. The increase in MDA content in the rat brain homogenates incubated with $\mathrm{Fe}^{2+}$ could be as result of the generation of hydroxy radicals generated from Fenton reaction. The decrease in brain MDA content by Capsicum spp. may be due to their ability to scavenge the hydroxyl radicals so generated. Quinolinic acid (QA) had been reported to activate neurons expressing NMDA receptors and glutamate-type excitotoxicity [36]. The mechanism through which QA induces lipid peroxidation has been linked to free radical generation resulting from overstimulation of NMDA receptors. Increases in QA concentration are known to be associated with several neurodegenerative diseases including Alzheimer's disease [37]. Free radical scavengers and antioxidant enzyme inducers can protect neuronal tissue against the oxidotoxicity of QA under in vitro and in vivo conditions $[38,39]$. Thus the mechanism by which extracts from the Capsicum spp. were able to lower 


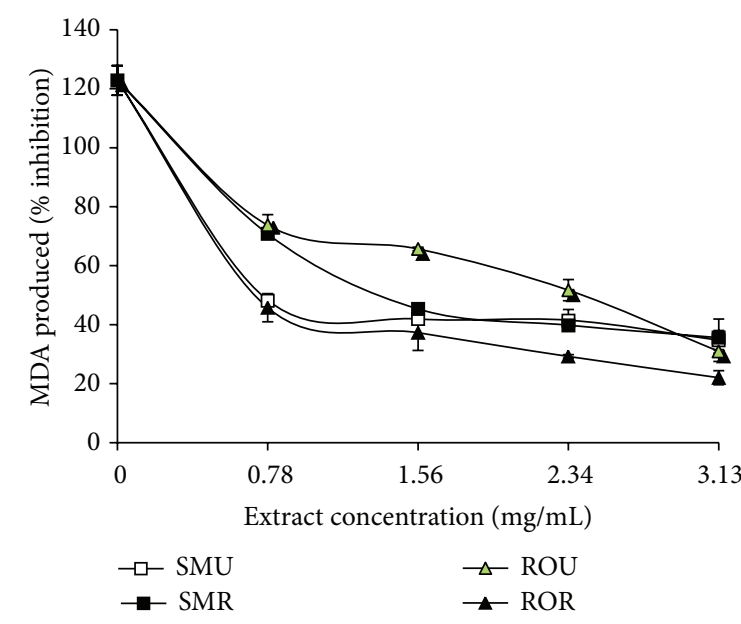

(a)

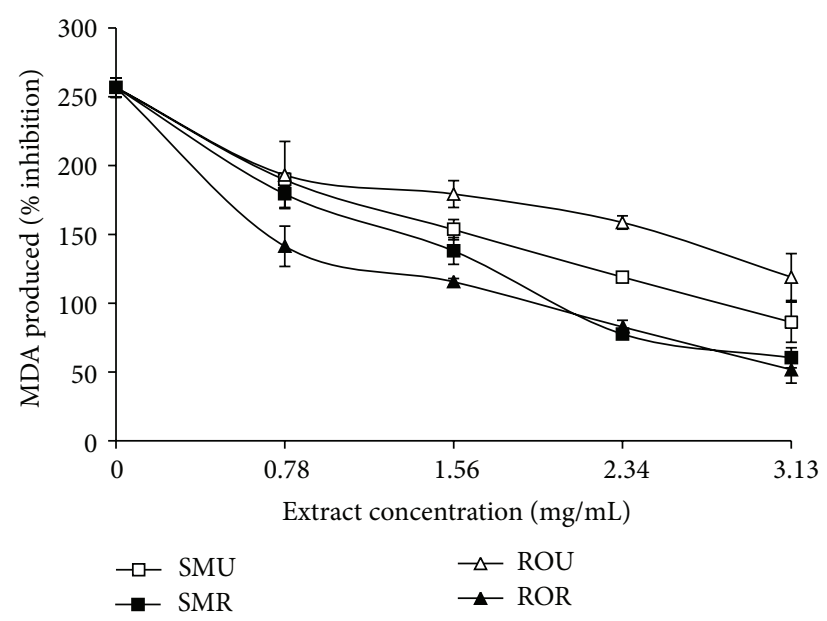

(b)

FIGURE 3: (a) Inhibition of $\mathrm{Fe}^{2+}$ induced lipid peroxidation in the brain by aqueous extract of Capsicum spp. (b) Inhibition of quinolinic acid induced lipid peroxidation in the brain by phenolic extracts of Capsicum spp. SMU: Capsicum annuum var. accuminatum (unripe). SMR: Capsicum annuum var. accuminatum (ripe). ROU: Capsicum chinense (unripe). ROR: Capsicum chinense (ripe).

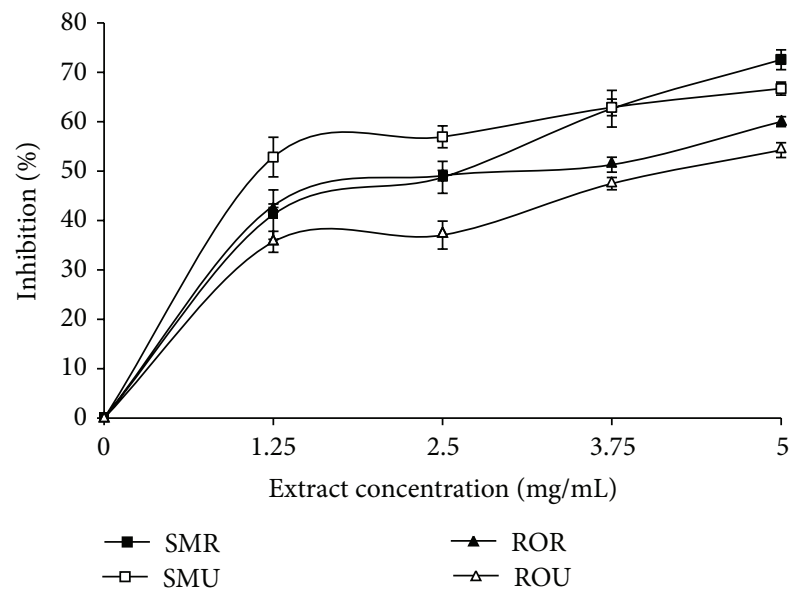

FIGURE 4: Inhibition of acetylcholinesterase by aqueous extract of Capsicum spp. SMU: Capsicum annuum var. accuminatum (unripe). SMR: Capsicum annuum var. accuminatum (ripe). ROU: Capsicum chinense (unripe). ROR: Capsicum chinense (ripe).

the increased generation of MDA in brain tissues could have been through scavenging of free radicals implicated in the overstimulation of NMDA receptors.

So far, inhibition of cholinesterases has proven to be the most effective approach in clinical management of AD. Acetylcholinesterase (AChE) and butyrylcholinesterase $(\mathrm{BuChE})$ are the two cholinesterases present in the brain with acetylcholinesterase being the most dominant making up about $80 \%$ while the remaining $20 \%$ represents butyrylcholinesterase. Acetylcholine, a neuronal signaling molecule, is found to be depleted in $\mathrm{AD}$ brain and has been linked to decline in cognitive function observed in $A D$ sufferers; hence acetylcholinesterase inhibitors (AChEI) have

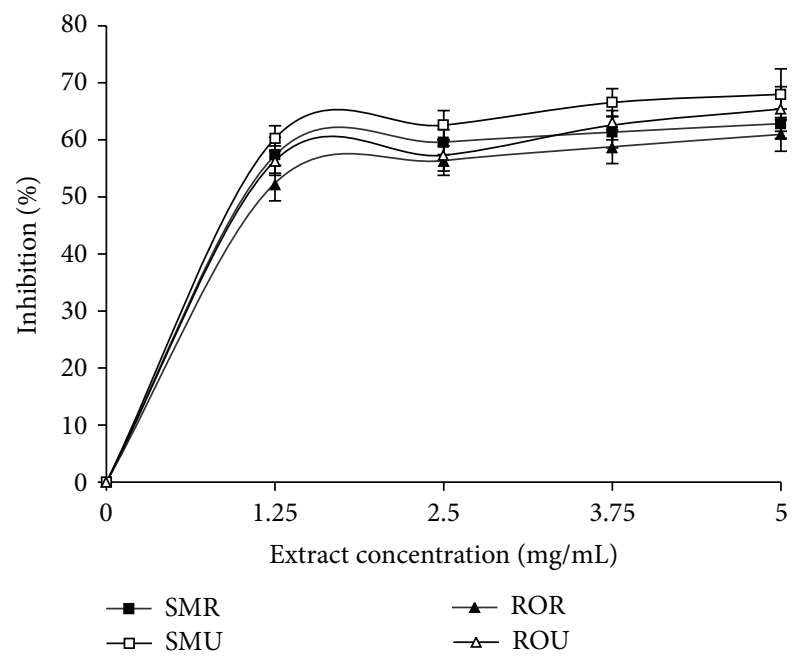

FIGURE 5: Butyrylcholinesterase inhibition by aqueous extract of Capsicum spp. SMU: Capsicum annuum var. accuminatum (unripe). SMR: Capsicum annuum var. accuminatum (ripe). ROU: Capsicum chinense (unripe). ROR: Capsicum chinense (ripe).

become important in the regulation of $\mathrm{AChE}$ and prolonging the acetylcholine levels at the synaptic clefts. The AChE inhibition by the pepper extracts used in this study agrees with previous studies where some plants and their products were found useful as acetylcholinesterase inhibitors (AChEI), some of which include Ginkgo biloba [40] and Quisqualis indica Linn [41]. Furthermore, inhibition of BuChE is also considered as a therapeutic strategy, in the AD brain, as it has been implicated in the aggregation of amyloid beta peptides associated with neurodegenerative processes and observed clinical dementia [42]. The ratio of BuChE to AChE changes drastically from about 0.5 to as high as 11 . This increase in 
BuChE and decline in AChE suggest that BuChE could be a more important therapeutic target. It is therefore noteworthy that the extracts showed a higher inhibition for BuChE than AChE [43].

\section{Conclusion}

This study has shown that aqueous extract from Capsicum spp. have strong antioxidant capacity. The ripe fruits however displayed a more potent antioxidant capacity compared to their unripe counterparts. Furthermore, these extracts were also able to inhibit the two cholinesterases linked to AD. This is indicative of possible nutritional strength of Capsicum spp. as a possible dietary source of palliative/preventive targets for AD.

\section{Conflict of Interests}

The authors declare that there is no conflict of interests regarding the publication of this paper.

\section{References}

[1] S. Salloway, R. Sperling, N. C. Fox et al., "Two phase 3 trials of Bapineuzumab in mild-to-moderate Alzheimer's disease," The New England Journal of Medicine, vol. 370, no. 4, pp. 322-333, 2014.

[2] R. Brookmeyer, E. Johnson, K. Ziegler-Graham, and H. M. Arrighi, "Forcasting the global burden of Alzheimer's disease," Alzheimer's and Dement, vol. 3, no. 3, pp. 186-191, 2007.

[3] E. T. Tzavara, F. P. Bymaster, C. C. Felder et al., "Dysregulated hippocampal acetylcholine neurotransmission and impaired cognition in M2, M4 and M2/M4 muscarinic receptor knockout mice," Molecular Psychiatry, vol. 8, no. 7, pp. 673-679, 2003.

[4] R. Schliebs, "Basal forebrain cholinergic dysfunction in Alzheimer's disease-interrelationship with $\beta$-amyloid, inflammation and neurotrophin signaling," Neurochemical Research, vol. 30, no. 6-7, pp. 895-908, 2005.

[5] M. N. Sabbagh, M. R. Farlow, N. Relkin, and T. G. Beach, "Do cholinergic therapies have disease-modifying effects in Alzheimer's disease?" Alzheimer's and Dementia, vol. 2, no. 2, pp. 118-125, 2006.

[6] S. L. Rogers, R. S. Doody, R. C. Mohs, and L. T. Friedhoff, "Donepezil improves cognition and global function in Alzheimer disease: a 15-week, double-blind, placebo-controlled study," Archives of Internal Medicine, vol. 158, no. 9, pp. 10211031, 1998.

[7] R. J. van Marum, "Current and future therapy in Alzheimer's disease," Fundamental and Clinical Pharmacology, vol. 22, no. 3, pp. 265-274, 2008.

[8] G. Pepeu and M. G. Giovannini, "Cholinesterase inhibitors and beyond," Current Alzheimer Research, vol. 6, no. 2, pp. 86-96, 2009.

[9] E. Mariani, M. C. Polidori, A. Cherubini, and P. Mecocci, "Oxidative stress in brain aging, neurodegenerative and vascular diseases: an overview," Journal of Chromatography B, vol. 827, no. 1, pp. 65-75, 2005.

[10] S. J. Stohs and D. Bagchi, "Oxidative mechanisms in the toxicity of metal ions," Free Radical Biology and Medicine, vol. 18, no. 2, pp. 321-336, 1995.
[11] G. Minotti and S. D. Aust, "The role of Iron in oxygen mediated lipid peroxidation," Free Radical Biology and Medicine, vol. 3, pp. 379-387, 1987.

[12] M. P. Almajano, I. Vila, and S. Gines, "Neuroprotective effects of white tea against oxidative stress-induced toxicity in striatal cells," Neurotoxicity Research, vol. 20, no. 4, pp. 372-378, 2011.

[13] M. Materska and I. Perucka, "Antioxidant activity of the main phenolic compounds isolated from hot pepper fruit (Capsicum annuum L.)," Journal of Agricultural and Food Chemistry, vol. 53, no. 5, pp. 1750-1756, 2005.

[14] J. L. Guil-Guerrero, C. Martínez-Guirado, M. del Mar Rebolloso-Fuentes, and A. Carrique-Pérez, "Nutrient composition and antioxidant activity of 10 pepper (Capsicum annuun) varieties," European Food Research and Technology, vol. 224, no. 1, pp. 1-9, 2006.

[15] P. G. C. Odeigah, B. Oboh, and I. O. Aghalokpe, “The characterization of Nigerian varieties of pepper, Capsicum annuum and Capsicum frutescens by SDS- polyacrylamide gel electrophoresis of seed proteins," Genetic Resources and Crop Evolution, vol. 46, no. 2, pp. 127-131, 1999.

[16] M. R. Loizzo, R. Tundis, F. Menichini, G. A. Statti, and F. Menichini, "Influence of ripening stage on health benefits properties of Capsicum annuum var. cuminatum L.: in vitro studies," Journal of Medicinal Food, vol. 11, no. 1, pp. 184-189, 2008.

[17] R. Tundis, M. R. Loizzo, F. Menichini et al., "Comparative study on the chemical composition, antioxidant properties and hypoglycaemic activities of two Capsicum annuum L. cultivars (Acuminatum small and Cerasiferum)," Plant Foods for Human Nutrition, vol. 66, no. 3, pp. 261-269, 2011.

[18] V. L. Singleton, R. Orthofer, and R. M. Lamuela-Raventos, "Analysis of total phenols and other oxidation substrates and antioxidants by means of folin-ciocalteu reagent," Methods in Enzymology, vol. 299, pp. 152-178, 1998.

[19] R. Re, N. Pellegrini, A. Proteggente, A. Pannala, M. Yang, and C. Rice-Evans, "Antioxidant activity applying an improved ABTS radical cation decolorization assay," Free Radical Biology and Medicine, vol. 26, no. 9-10, pp. 1231-1237, 1999.

[20] M. Oyaizu, "Studies on products of browning reaction: antioxidative activity of products of browning reaction prepared from glucosamine," The Japanese Journal of Nutrition and Dietetics, vol. 44, pp. 307-315, 1986.

[21] N. A. V. Bellé, G. D. Dalmolin, G. Fonini, M. A. Rubin, and J. B. T. Rocha, "Polyamines reduces lipid peroxidation induced by different pro-oxidant agents," Brain Research, vol. 1008, no. 2, pp. 245-251, 2004.

[22] H. Ohkawa, N. Ohishi, and K. Yagi, "Assay for lipid peroxides in animal tissues by thiobarbituric acid reaction," Analytical Biochemistry, vol. 95, no. 2, pp. 351-358, 1979.

[23] G. L. Ellman, K. D. Courtney, V. Andres Jr., and R. M. Featherstone, "A new and rapid colorimetric determination of acetylcholinesterase activity," Biochemical Pharmacology, vol. 7, no. 2, pp. 88-95, 1961.

[24] D. A. Butterfield, A. Castenga, C. B. Pocernich, J. Drake, G. Scapagnini, and V. Calabrese, "Nutritional approaches to combat oxidative stress in Alzheimer's diseases," The Journal of Nutritional Biochemistry, vol. 13, pp. 444-461, 2002.

[25] G. Munch, A. Simm, K. L. Double, and P. Rieder, "Oxidative stress and advanced glycation end products - parts of a vicious circle in neurodegeneration?" Alzheimer's Disease Review, vol. 1, pp. 71-74, 1996. 
[26] M. A. Lovell, W. D. Ehmann, S. M. Butler, and W. R. Markesbery, "Elevated thiobarbituric acid-reactive substances and antioxidant enzyme activity in the brain in Alzheimer's disease," Neurology, vol. 45, no. 8, pp. 1594-1601, 1995.

[27] G. Oboh and J. B. T. Rocha, "Distribution and antioxidant activity of polyphenols in ripe and unripe tree pepper (capsicum pubescens)," Journal of Food Biochemistry, vol. 31, no. 4, pp. 456473, 2007.

[28] W. R. Markesbery and J. M. Carney, "Oxidative alterations in Alzheimer's disease," Brain Pathology, vol. 9, no. 1, pp. 133-146, 1999.

[29] I. Klimczak, M. Małecka, M. Szlachta, and A. GliszczyńskaŚwigło, "Effect of storage on the content of polyphenols, vitamin $\mathrm{C}$ and the antioxidant activity of orange juices," Journal of Food Composition and Analysis, vol. 20, no. 3-4, pp. 313-322, 2007.

[30] Y. Kiselova, D. Ivanova, T. Chervenkov, D. Gerova, B. Galunska, and T. Yankova, "Correlation between the in vitro antioxidant activity and polyphenol content of aqueous extracts from Bulgarian herbs," Phytotherapy Research, vol. 20, no. 11, pp. 961965, 2006.

[31] G. K. Jayaprakasha, B. Girennavar, and B. S. Patil, "Radical scavenging activities of Rio Red grapefruits and Sour orange fruit extracts in different in vitro model systems," Bioresource Technology, vol. 99, no. 10, pp. 4484-4494, 2008.

[32] D. Amic, D. Davidovic-Amic, D. Beslo, and N. Trinajstic, "Structure-radical scavenging activity relationship of flavonoids," Croatica Chemica Acta, vol. 76, no. 1, pp. 55-61, 2003.

[33] B. Halliwell, "Free radicals, antioxidants, and human disease: curiosity, cause, or consequence?” The Lancet, vol. 344, no. 8924, pp. 721-724, 1994.

[34] R. A. Floyd and J. M. Carney, "Free radical damage to protein and DNA: mechanisms involved and relevant observations on brain undergoing oxidative stress," Annals of Neurology, vol. 32, supplement 1, pp. S22-S27, 1992.

[35] G. Oboh, R. L. Puntel, and J. B. T. Rocha, "Hot pepper (Capsicum annuum, Tepin and Capsicum chinese, Habanero) prevents $\mathrm{Fe}^{2+}$-induced lipid peroxidation in brain-in vitro," Food Chemistry, vol. 102, no. 1, pp. 178-185, 2007.

[36] G. J. Guillemin, V. Meininger, and B. J. Brew, "Implications for the kynurenine pathway and quinolinic acid in amyotrophic lateral sclerosis," Neurodegenerative Diseases, vol. 2, no. 3-4, pp. 166-176, 2006.

[37] J. Cabrera, R. J. Reiter, D.-X. Tan et al., "Melatonin reduces oxidative neurotoxicity due to quinolinic acid: in vitro and in vivo findings," Neuropharmacology, vol. 39, no. 3, pp. 507-514, 2000.

[38] T. W. Stone, "Neuropharmacology of quinolinic and kynurenic acids," Pharmacological Reviews, vol. 45, no. 3, pp. 309-379, 1993.

[39] D. Santamaría, V. Espinoza-González, C. Ríos, and A. Santamaría, "N $\omega$-nitro-L-arginine, a nitric oxide synthase inhibitor, antagonizes quinolinic acid-induced neurotoxicity and oxidative stress in rat striatal slices," Neurochemical Research, vol. 24, no. 7, pp. 843-848, 1999.

[40] A. Das, G. Shanker, C. Nath, R. Pal, S. Singh, and H. K. Singh, "A comparative study in rodents of standardized extracts of Bacopa monniera and Ginkgo biloba: anticholinesterase and cognitive enhancing activities," Pharmacology Biochemistry and Behavior, vol. 73, no. 4, pp. 893-900, 2002.

[41] P. Wetwitayaklung, C. Limmatvaipirat, T. Phaechamud, and S. Keokitichai, "Kinetics of Acetylcholinesterase inhibition of
Quisqualis indica Linn flower extract," Silpakorn University Science and Technology Journal, vol. 1, no. 2, pp. 20-28, 2007.

[42] A. L. Guillozet, J. F. Smiley, D. C. Mash, and M.-M. Mesulam, "Butyrylcholinesterase in the life cycle of amyloid plaques," Annals of Neurology, vol. 42, no. 6, pp. 909-918, 1997.

[43] N. H. Greig, T. Utsuki, Q. S. Yu et al., "A new therapeutic target in Alzheimer's disease treatment: attention to butyryloholinesterase," Current Medical Research and Opinion, vol. 17, no. 3, pp. 159-165, 2001. 

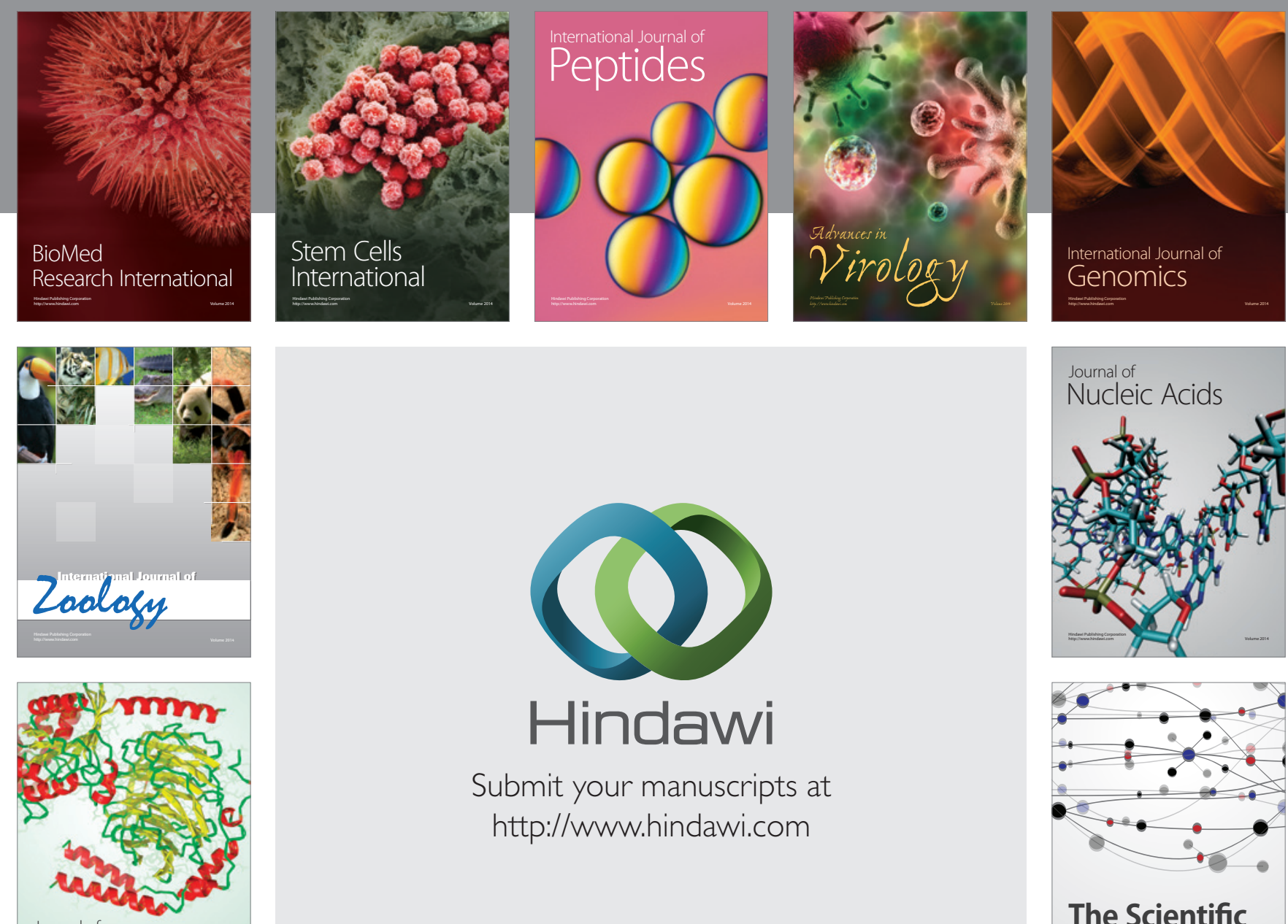

Submit your manuscripts at

http://www.hindawi.com

Journal of
Signal Transduction
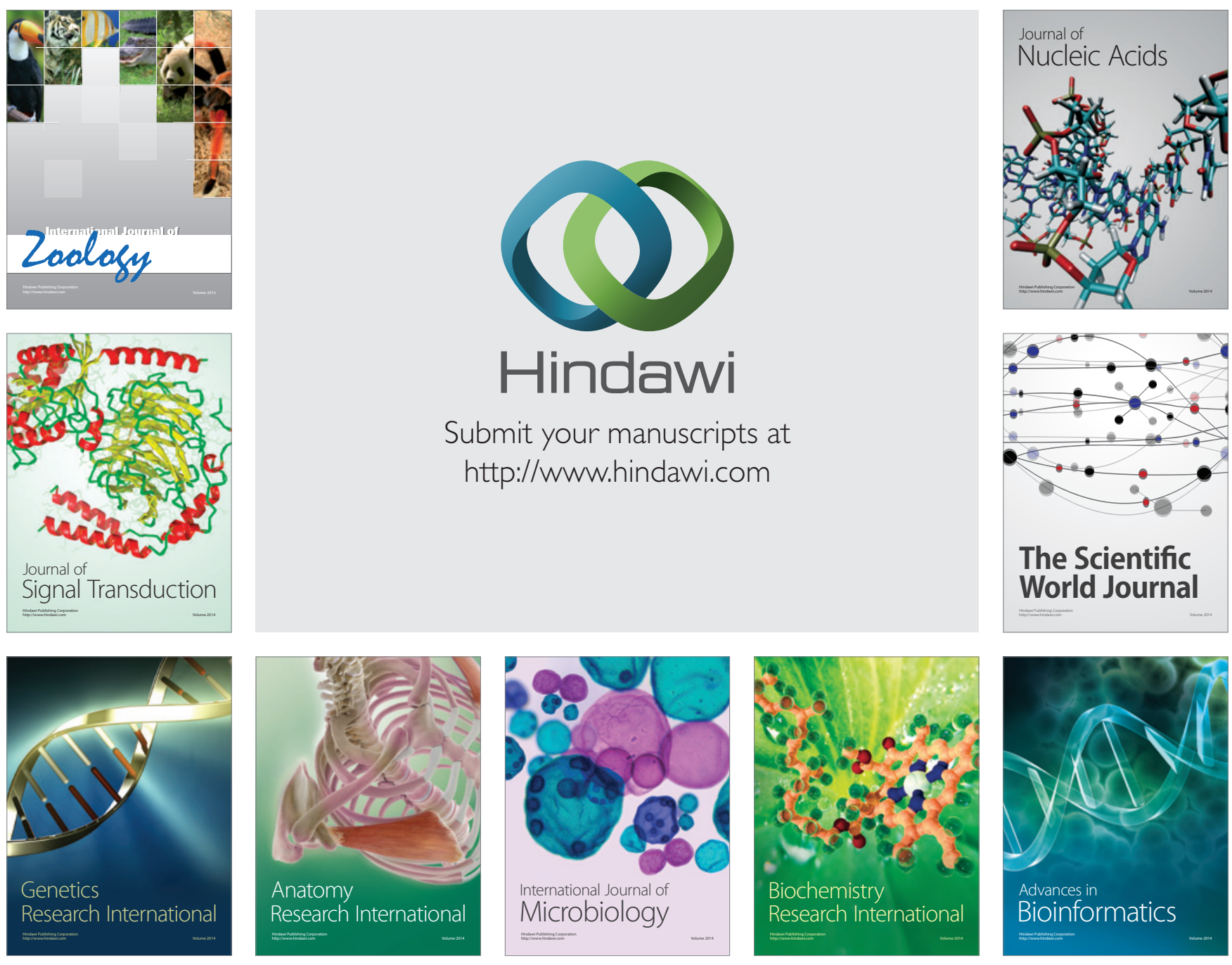

The Scientific World Journal
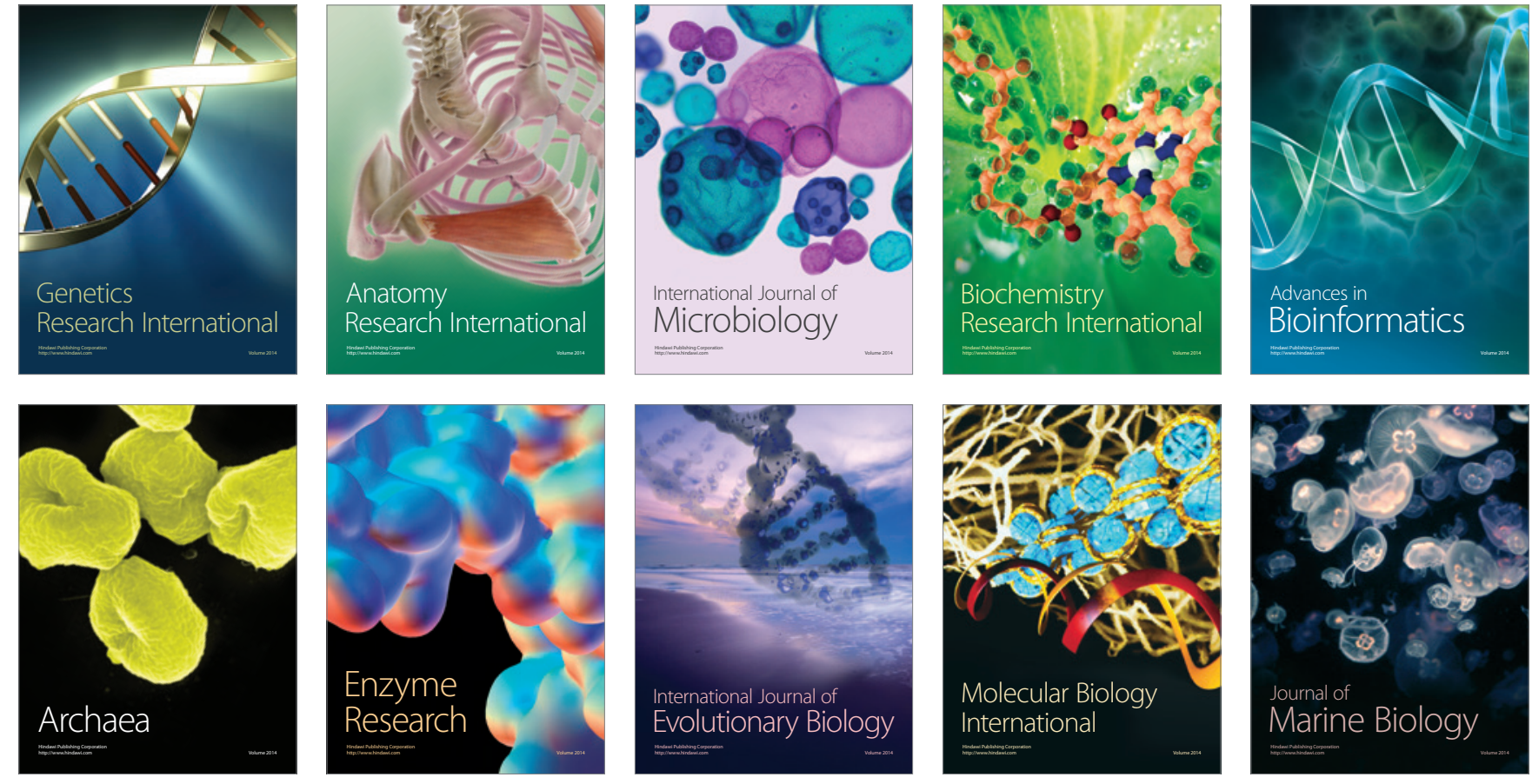